\title{
性周期が自律神経活動とQT dispersionに及ぼす影響
}

堤 由美子*1 古川かおり*2 菅野有紀*2 丸山良子*2

佐藤 廣*1 山本真千子*2

閉経後の女性において虚血性心疾患, 心臓突然死の発生率が増加することはよく 知られている. この際自律神経活動にも変化をきたすと考えられているが, 詳細は 明らかにされていない，今回我々は，このメカニズム理解の一助として，閉経前女 性の正常性周期における性ホルモンの分泌変化が自律神経活動, および心電図所見 に及ぼす影響について検討した，正常性周期をもつ若年女性において，卵胞期と黄 体期に，QTc，QT dispersion(QTD)，心拍変動解析を行い，2期を比較した.

黄体期には心拍数, 収縮期血圧が上昇し, 高周波成分パワーが減少した。 また, QTCが不変であつたにも関わらず，QTDが延長した，以上より，若年女性の性周 期においても，黄体期には迷走神経活動が衰退し，心室内再分極過程のばらつきが 増大することがわかつた。この結果は, 閉経後の女性において虚血性心疾患, 心臓 突然死の発生率が増加することの理解に有用と思われた.

(心電図, $2003 ; 23: 207 \sim 212$ )

\section{I ・はじめに}

欧米では虚血性心疾患が女性の死亡率の第 1 位を 占め, 近年, 日本でも生活習慣の変化とともに女性 の動脈硬化性疾患が増加しつつある ${ }^{1)}$. 動脈硬化性

\begin{tabular}{|ll|}
\hline Keywords & - 性周期 \\
& - 自律神経活動 \\
& $\bullet$ QT dispersion \\
\hline
\end{tabular}

*1心臓血管研究所

（T 106-0032 東京都港区六本木7-3-10）

*2宮城大学看護学部
疾患の発生率は，男女間で異なり，女性の発生率は 閉経前には低く，閉経後に上昇するが，これには閉 経に伴う女性ホルモン，特にエストロゲンの低下が 関与していると言われている ${ }^{1)}$. 閉経後女性に対す るエストロゲン補充療法は, 虚血性心疾患の発生率

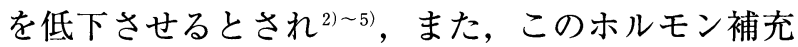
療法は更年期女性の自律神経機能の改善にも有効で あるという報告 ${ }^{6)}{ }^{7}$ がある。

自律神経と虚血性心疾患，および心臓突然死りス クは密接な関係があるとされ，虚血性心疾患の発症 には自律神経が大きく関与し，かつ，突然死をもた

Influence of normal menstrual cycle on autonomic nervous activity and QT dispersion

Yumiko Tsutsumi, Kaori Furukawa, Yuki Kanno, Ryoko Maruyama, Hiroshi Sato, Machiko Yamamoto

2002 年 10 月 9 日 原稿受領 $/ 2003$ 年 1 月 8 日 揭載承認 
らす重要な誘因は自律神経のインバランスにあると 考えられている.このような観点から欧米において ATRAMI (Autonomic Tone and Reflexes After Myocardial Infarction) という多施設共同研究が行わ れており，おもに自律神経のバランスの指標を心拍 変動スペクトル解析 (Heart Rate Variability : HRV) 等から求め，その低值を示すものが突然死のリスク が高く，予後が悪いという報告が出された ${ }^{8)}$.

一方QTc dispersionは心室内再分極過程のばらつ きを簡便に評価する方法として広く用いられている ${ }^{91}$. 心室再分極過程のばらつきの増大は致死性不整脈の 発生に関与することが知られており ${ }^{101,111}$ ， QTc dispersionが各種心疾患で増大することはその予後 と密接な関係があると言われている ${ }^{101,12), 13)}$.また, 心臓電気現象が自律神経活動の影響を強くうけるこ とから，QTc dispersionも自律神経により修飾され るということが報告されている ${ }^{14)}$.

これらの $2 つ の$ 指標を用いて, 閉経後女性の虚血 性心疾患の発症率, 心蔵突然死リスクが上昇すると いうメカニズムの理解とそれを子防，阻止する対策 の一助として, 閉経前女性の正常性周期における女 性ホルモンバランスの変化が自律神経系活動, およ びQTc dispersionに及ぼす影響について検討した。

\section{II. 対 象}

健康診断にて異常が認められず，排卵性正常月経 周期をもち, 本研究の主旨を理解し, 同意を得た女 子大学生 12 名 (平均年齢 20.8 歳) を対象者とした. 対 象者は不整脈を有する者, 正常月経周期を示さなかっ た例は除外した。正常月経周期の判定は, 対象者全 員が早朝覚醒時, 舌下にて体温を測定し, 記録した Premenstrual Syndrome(PMS) メモリーを基に, 高 温相と低温相の 2 相性を有するか否かで行った. 2 相性の定義は, 高温相と低温相の体温差が約 $0.4{ }^{\circ} \mathrm{C}$ であることとし, 平均正常周期は 25〜38日とした ${ }^{15)}$.

\section{III. 方 法}

前述の対象者に対して卵胞期, 黄体期に, ベッド
上安静仰臥位にて標準 12 誘導心電図を測定した。そ ののち, 心電図モニターシステム (日本光電社製 STU-1100)，トノメトリー（日本コーリン社製 JENTOW7700) を用いて連続的に心電図 (胸部双極 誘導：CM-5), 血圧をモニターした。なお，トノメ トリーは右手首橈骨動脈上に装着し，右前腕が固定 された状態で測定した。脈波・血圧・心拍が安定し たことを確認した後，測定を開始した。データの測 定は，安静仰臥位にて15分間以上行い，測定した データのうち最も安定した 5 分間のデータを心拍, 血圧，HRVの解析に使用した。測定時間は，自律神 経の日内変動を考慮したうえで午前 10 時〜午後 3 時 の時間帯とし，被験者は前日は十分な睡眠をとる， 当日はカフェインなどの刺激物は摂取しない, 食事 は3時間前までに取るなど，条件を一定にした。ま た室温などほぼ同一環境のもとで施行した。

\section{QTC}

標準 12 誘導心電図は $25 \mathrm{~mm} / \mathrm{sec}, 50 \mathrm{~mm} / \mathrm{sec}$ の 2 種類のスピードで記録し，計測は同一計測者が $25 \mathrm{~mm} / \mathrm{sec}$ で記録した心電図を参考にしながら $50 \mathrm{~mm} / \mathrm{sec} て ゙$ 記録したものを計測した。測定した心 電図から 12 誘導すべてのQ-T 間隔を計測し，Bazzet の補正式より QTc 時間を求め, 第 II 誘導の QTcを 各例におけるQTcとした。

\section{QTc dispersion (QTD)}

全 12 誘導で求められた QTcの最大 $\mathrm{QTc}$ と最小 QTcの差を各例におけるQTDとした.

\section{3. 心拍 (HR)}

前述の 5 分間の R-R 間隔より平均心拍数を求めた。

4. 収縮期血圧 (SBP), 拡張期血圧 (DBP)

トノメトリーから得られた前述の安定した5分間 のデー夕を平均して $\mathrm{SBP} \cdot \mathrm{DBP}$ 求めた。

\section{5. 心拍変動スペクトル解析 (HRV)}

心電図モニターから得られた 5 分間の $R-R$ 間隔時 系列を FFT 法にて解析し，0.04〜0.15Hz を Low frequency $(\mathrm{LF}), 0.15 \sim 0.5 \mathrm{~Hz}$ を High frequency $(\mathrm{HF})$ とし，LF，HFの比を算出した。迷走神経活動の指 標を $\mathrm{HF}$ ，交感神経活動の指標を $\mathrm{LF} / \mathrm{HF}$ とした ${ }^{16)}$.

JPN. J. ELECTROCARDIOLOGY Vol. 23 No. 22003 
HR

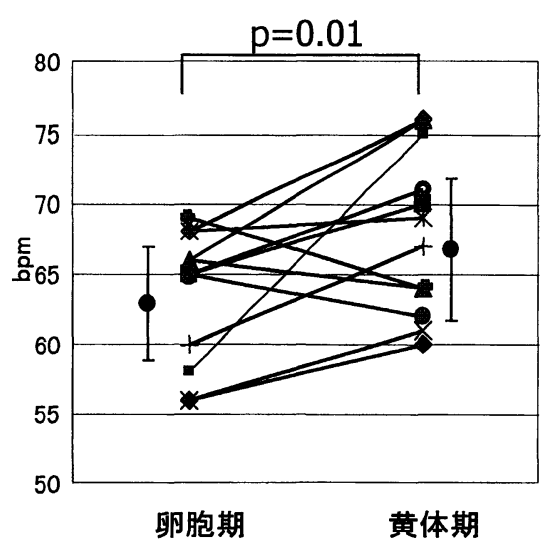

SBP

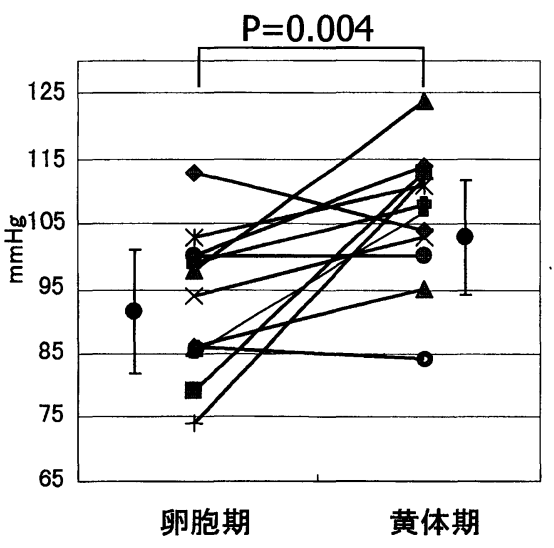

DBP

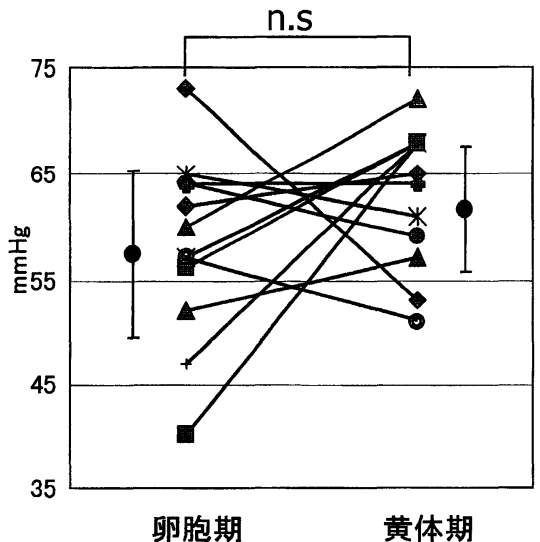

図1 卵胞期, 黄体期における心拍数, 血圧の変化

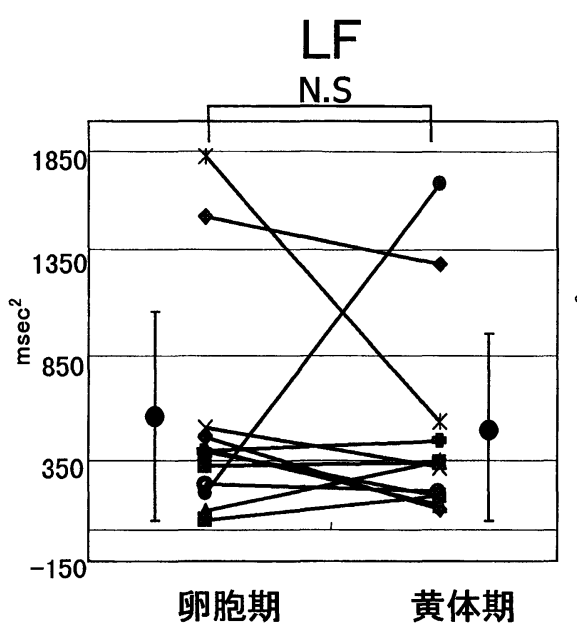

HF

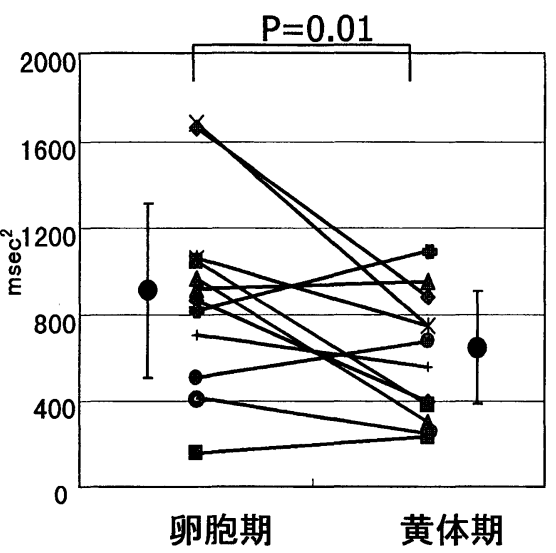

$\mathrm{LF} / \mathrm{HF}$

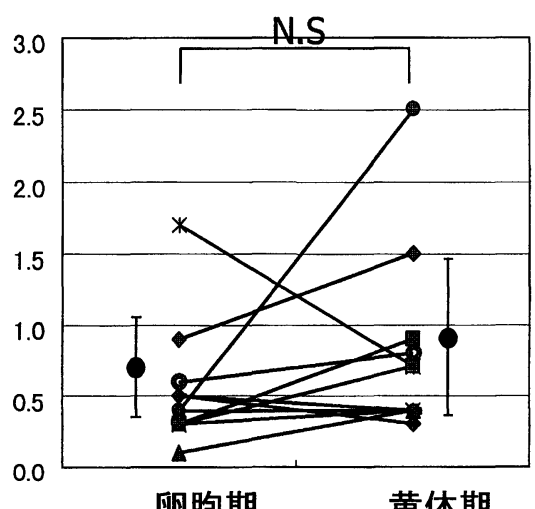

図2 卵胞期, 黄体期における HRV 指標の変化

得られたデータより卵胞期と黄体期における心 拍, 血圧, QTc, QTD, LF, HF, LF/HFについ て比較・検討した. 各々の測定值は平均值 \pm 標準偏 差で表し, 統計処理は $t$ 検定 (paired $t$ test)を用い, 危険率 $5 \%$ 未満を有意とした。

\section{IV. 結 果}

\section{1. 心拍数, 血圧}

心拍数 (HR) は卵胞期では $64 \pm 5 \mathrm{bpm}$, 黄体期で は68 $68 \mathrm{bpm}$ であり, 卵胞期に比べ黄体期において, 有意に $(\mathrm{p}<0.05)$ 増加した. SBPは, 卵胞期には
$93 \pm 11 \mathrm{mmHg}$ ，黄体期には $106 \pm 10 \mathrm{mmHg}$ であり 卵胞期に比べ黄体期において有意に $(\mathrm{p}<0.01)$ 上昇 した。また，DBPは卵胞期には $58 \pm 9 \mathrm{mmHg}$, 黄体 期には $63 \pm 7 \mathrm{mmHg}$ であり卵胞期と黄体期の間に有 意差はなかった(図1).

\section{HRV}

$\mathrm{LF}$ は卵胞期では $532 \pm 559 \mathrm{msec}^{2}$, 黄体期では $478 \pm 502 \mathrm{msec}^{2}$ であり，卵胞期と黄体期の間に有意 差がなかったＨF は卵胞期では $901 \pm 451 \mathrm{msec}^{2}$, 黄体期では $602 \pm 293 \mathrm{msec}^{2}$ であり，卵胞期に比べ黄 体期では有意に $(p<0.05)$ 減少した. LF/HFは卵胞 
QTc

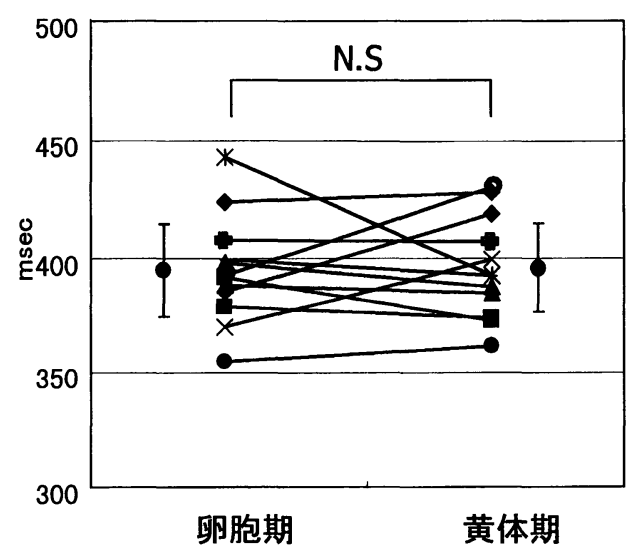

QTD

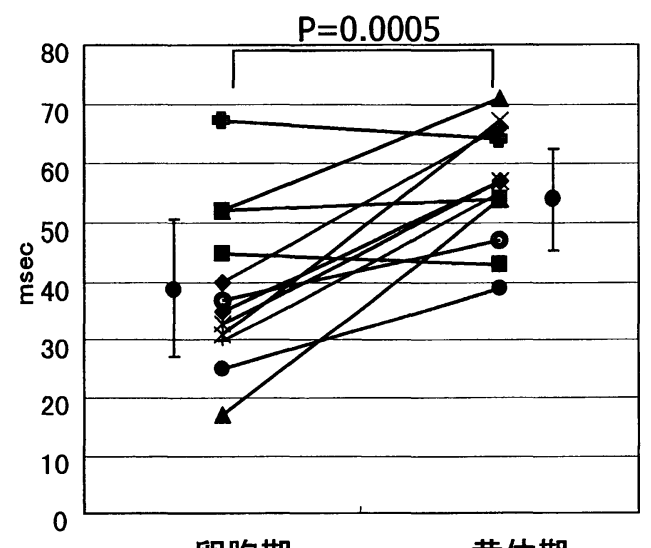

卵胞期
黄体期

図3 卵胞期，黄体期におけるQTC, QTDの変化

期では $0.5 \pm 0.4$, 黄体期では $0.8 \pm 0.6 て ゙ あ り$ 黄体期 でやや上昇するものの, 有意差はなかった(図2).

\section{QTC, QTD}

QTcは卵胞期では $394.8 \pm 23.3 \mathrm{msec}$ ，黄体期では $396 \pm 21.8 \mathrm{msec}$ であり，卵胞期と黄体期の間に有意 差がなかった。QTDは卵胞期では38.7 $\pm 13.6 \mathrm{msec}$,

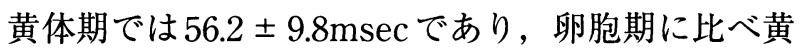
体期においてQTDは有意に( $\mathrm{p}<0.05)$ 増大した(図3).

\section{V. 考察}

虚血性心疾患 (CHD) は男性において発症頻度が高 く, 加齢に伴い増加する. Framingham研究では $\mathrm{CHD}$ の発症率の男女比は若年層では男性優位である が，加齢に伴いその差が縮小し，特に55歳以降でそ の傾向が強まると報告している ${ }^{1)}$. 女性高齢者にお けるCHDは閉経が大きく影響し，冠攣縮や微小循 環障害 (microvascular angina)の関与が推定されて いる ${ }^{1)}$.

近年，女性ホルモンの心血管系に対する保護作用 が注目されており, 特にエストロゲンは脂質代謝, 血圧，糖代謝といった冠危険因子に対する作用に加 えて, 心血管系に直接作用する.エストロゲンは NO 産生を増加させ内皮依存性に血管を拡張させる ${ }^{11}$.
また，閉経後女性におけるホルモン補充療法が虚血 性心疾患の発症率を低下させ，それと同時に自律神 経活動も改善するといわれている2) 5).

そこで今回閉経後女性の虚血性心疾患，心臓突然 死リスクが上昇するメカニズムを理解するために， 閉経前女性の性周期による自律神経系および QT dispersionの変化を検討した。自律神経活動は心疾 患患者の予後，心臓突然死と密接な関係があり ${ }^{8)}$, QT dispersionの延長は心室再分極相のばらつきを 表し，致死性不整脈の指標とされている．かつ，この QT dispersion は自律神経活動により修飾される ${ }^{14)}$.

その結果, 卵胞期に比べ, 黄体期では心拍数が増 加, 収縮期血圧が上昇し, QT dispersionが延長, $\mathrm{HF}$ が減少することが明らかとなった．卵胞期に比 べ黄体期において心拍数が増加した理由として2つ のことが考えられる．1つには黄体期において，熱 産生作用をもつプロゲステロンが間脳の温度中枢に フィードバックするために ${ }^{17)}$ 体温が上昇し，体温が 上昇することで心拍数が増加したであろうこと．も う一方で，HFの減少にみられるように，迷走神経 活動が衰退したことにより心拍数が増加したことが 理由であると考えられた。 また，黄体期での収縮期 血圧の上昇については迷走神経の衰退の他に，エス 
トロゲンの減少による血管拡張作用の減弱が理由で あると考えられる。ささらに，QTcは卵胞期と黄体期 において不変であったが，黄体期においてQT dispersionは増大した. QT dispersionは自律神経活 動に影響をうけるので, 黄体期の迷走神経活動衰退 が一因であると考えられる．また，QT dispersion は冠攣縮性狭心症患者で臨床的に狭心症発作のない 無症候状態にすでに増大しており, ISDN投与で短 縮するという報告があるが，これは，非発作時にお いても自律神経異常や, 血管内皮障害による軽度の 血管収縮が存在しているためと考えられている ${ }^{18)}$. 閉経前女性の冠攣縮性狭心症患者の自然発作頻度は エストロゲンが減少する黄体期後期から月経期にか けて増加するという報告もあるが ${ }^{1)}$, 黄体期の QT dispersionの増大の理由の1つにエストロゲンの減 少に伴う血管拡張作用の減弱に起因するものもある のではないかと考えられる. 閉経後女性にみられる syndrome Xは冠微少血管病変における心筋虚血が 原因であると考えられているが，エストロゲン欠乏 の女性に多く見られるという報告がある ${ }^{1}$. syndrome Xの発生機序はエストロゲンの欠乏によ る冠微少血管の拡張不全, 特に内皮依存性拡張反応 の低下, 左室壁内における不均一な血管拡張に起因 する盗血現象, 冠血管攣縮が考えられている ${ }^{1)}$. 心 筋の血流量が不均一であれば, 心筋細胞の活動電位 持続時間のばらつきも増大すると考えられ，これが QT dispersionの増大となって現れると考えられる. 今回の若年女性における黄体期の QT dispersionの 増大は, 黄体期のエストロゲンの低下が同様の現象 を引き起こすと考えられないだろうか？

今回の研究は血中女性ホルモン濃度の測定を行っ ていないため, 以上の考察は推測の域を出ない.ま た，非侵襲的かつ簡便に心室再分極過程を評価する 方法として今回 QT dispersionを用いたが, QT dispersionには再現性, 测定者間の誤差 ${ }^{19)}$, 誘導法 (肢誘導を用いるか否か) ${ }^{200}$ などの問題点があり，よ り適した方法を模索する必要があると考える. 今後 はこれをふまえて, 心疾患のある女性, 閉経前後の
女性においても検討し，女性と心疾患の関係を明ら かにしていきたい.

\section{[文献]}

1 ）村山正博監修：女性における虚血性心疾患：天野恵子, 大川真一郎編集, 第1版. 医学書院, 東京, $2000 ; \mathrm{P} 1$ 〜 2, P29, P43, P55 65, P67 85

2 ) Belchetz PE : Hormone treatment of postmenopausal women. N Engl J Med, $1994 ; 330$ : 1062 1071

3 ) O’ Keefe JH Jr, Kim SD, Hall RR, Cochran VC. Lawhorn SR, McCallister BD : Estrogen replacement therapy after coronary angioplasty in women. J Am Coll Cardiol, $1997 ; 29: 1 \sim 5$

4 ) Grodstein F, Stampfer MJ, Manson JE, Colditz GA, Willett WC, Rosner B, Speizer FE. Hennekens $\mathrm{CH}$ : Postmenopausal estrogen and progestin use and the risk of cardiovascular disease. N Engl J Med, 1996 ; 335 : 453 $\sim 461$

5 ) Grady D, Rubin SM, Petitti DB, Fox CS, Black D, Ettinger B, Ernster VL, Cummings SR : Hormone therapy to prevent disease and prolong life in postmenopausal women. Ann Intern Med, $1992 ; 117$ : $1016 \sim 1037$

6 ）中野由紀子, 大島哲也, 小園亮次：エストロゲン補充が 自律神経活動およびQT 時間に及ぼす影響. Circ J, 1999； 63(1) : 552

7 ) 田中 修, 三宅良彦, 田中麻里子：ホルモン補充療法に よる更年期女性自律神経機能の改善. Circ J, $1999 ; 63(1)$ : 552

8 ) La Rovere MT, Bigger JT Jr, marcus FI, Mortara A, Camm AJ, Hohnloser SH, Nohara R, Scheartz PJ, On behalf of the ATRAMI Investigators : Prognostic value of depressed baroreflex sensitivity the ATRAMI study. Circulation, 1995 ; 92(Abstr Suppl) : I 77 I 91

9 ) Day CP, McComb JM, Campbell RW : QT dispersion : an indication of arrhythmia risk in patients with long QT intervals. Br Heart J, 1990 ; 63(6) : 342 344

10) Zareba W, Moss AJ, Cessie S : Dispersion of ventricular repolarization and arrhythmic cardiac death in coronary artery disease. Am J Cardiol, $1994 ; 74(6)$ : 550 553

11) Higham PD, Furniss SS, Campbell RW : QT dispersion and components of the $\mathrm{QT}$ interval in ischaemia and infarction. Br Heart J, $1995 ; 73(1): 32 \sim 36$

12) Zaidi M, Robert A, Fesler R, Derwael C, Brohet C : Dispersion of ventricular repolarization in dilated cardiomyopathy. Eur Heart J, $1997 ; 18(7): 1129 \sim 1134$

13) Zaidi M, Robert A, Fesler R, Derwael C, Brohet C : Dispersion of ventricular repolarization : a marker of 
ventricular arrhythmia in patients with previous myocardial infarction. Heart, $1997 ; 78(4)$ : 371 375

14）横山亜由美，佐藤伸之，赤坂和美：健常人における QT, QT dispersionの概日リズムと心拍変動との関係.心電 図, $1999 ; 19(5): 579$

15）松岡 恵：母性看護学. 日総研出版, 1997 ; P19

16) Yamamoto $Y$, Hughson RL : Coarsegraining spectral analysis : new method for studying heart rate variability. J Appl Physiol, $1991 ; 71$ : 1143 1150

17）小坂樹徳：新版看護学全書 34 母性看護学 1 , メヂカル フレンド社, $\mathrm{P} 16 \sim 17$

18）西崎光弘, 鈴木 誠, 足利貴志, 山分規義, 平岡昌和：
冠スパズムの QTc dispersion. 心臓, $1999 ； 31(4) ： 270$ 277

19）斉藤寬和, 野村敦宣, 加藤貴雄, 小野卓哉, 松本 真, 緒方憲一, 遠藤康実, 小林義典, 新 博次, 岸田 浩, 長 澤紘一, 早川弘一：QT間隔及びQT dispersionの再現 性と inter-observer variation. 第2 報. 心電図, 1997 ; $5: 573$

20) Statters DJ, Malik M, Ward DE, Camm AJ : QT dispersion. Problems of methodology and clinical significance. J Cardiovasc Electrophysiol, $1994 ; 5: 672 \sim$ 685 